\title{
Systematic Importance of Leaf Anatomical Characters in Some Species of Microcos Linn. Section Eumicrocos Burret. in Nigeria
}

\author{
Emmanuel Oyeniyi Shokefun ${ }^{*}$, Abiodun Emmanuel Ayodele1, \\ Akinwunmi Johnson Akinloye ${ }^{2}$ \\ ${ }^{1}$ Department of Botany, University of Ibadan, Ibadan, Nigeria \\ ${ }^{2}$ Department of Botany, Obafemi Awolowo University, Ile-Ife, Nigeria \\ Email: "eo.shokefun@ui.edu.ng, bayodele@yahoo.com, akinloye johnson@yahoo.com
}

Received 6 October 2015; accepted 24 January 2016; published 27 January 2016

Copyright (C) 2016 by authors and Scientific Research Publishing Inc.

This work is licensed under the Creative Commons Attribution International License (CC BY). http://creativecommons.org/licenses/by/4.0/

c. (i) Open Access

\begin{abstract}
The leaf anatomy of six Microcos L. species belonging to section Eumicrocos in Nigeria was investigated by transverse sectioning of the lamina and examined by light microscope to determine their taxonomic significance in species delimitation and classification. The common anatomical characteristics in all the species are as follows: the uniseriate epidermis; the hypostomatic and bifacial leaves; presence of 2 layers of palisade tissues; presence of bundle sheath extension to both epidermises; presence of glandular and non-glandular trichomes; presence of secretory ducts on abaxial surface; presence of druse crystal in the mesophyll and midrib and; sclerenchyma cells associated with the phloem. Anatomical characters which are significant for species delimitation include: the presence/absence of sclerenchyma cells associated with the xylem in the midrib; presence/ absence of starch grains in the mesophyll and midrib; the presence/absence of secretory ducts on the adaxial surface of the midrib; the presence/absence of medullary plates in midrib; the number of secretory ducts in the midrib and the midrib adaxial outline. The section can be separated into two distinct groups based on the number of spongy tissue layers in the mesophyll, number of sclerenchyma cells associated with the phloem and presence/absence of sclerenchyma cells in xylem both groupings correlated with those obtained from foliar epidermal and pollen characters. The importance of these characters is discussed in relation to the taxonomy of the taxon.
\end{abstract}

\section{Keywords}

Leaf Anatomy, Microcos, Taxonomy, Nigeria

\footnotetext{
${ }^{*}$ Corresponding author.
} 


\section{Introduction}

The genus Microcos Linn. contains about 60 to 80 species distributed over Asia and Tropical Africa [1] [2]. It is a member of the tribe Grewieae made up of about 14 genera [3] in the subfamily Grewioideae and family Malvaceae s.l [1]. Members are shrubs, woody climbers and small trees with stellate branchlets. The inflorescence is a panicle with long peduncle, short flower buds and glabrous ovary [4] [5]. The stylar apex is narrow with unlobed stigma while the unlobed fruit is monopyrene [6]. The leaves and fruits of most species in the genus are of nutritive and medicinal value mostly in the treatment of dysentery and intestinal complaints [7]. However, their reputation in the making of household utensils, canoe paddle and farm house construction is more pronounced. In West Africa, 8 species have been recorded in evergreen montane or swamps in the lowland rainforest [8]. Nigeria is the major diversity centre of Microcos in West Africa [8]. The genus Microcos has been subjected to a number of studies mainly based on morphology [1] [5] [6] [9]-[11], anatomy [2] [12]-[15] and palynology [9] [16] [17] information. Reference [6] employs morphological characters of the flower and stipule to recognize two subgenera: subg. Microcos Burret (species from Africa and Asia) and Eumeriandra Burret (species from Moluccas and New Guinea). The subg. Microcos was further divided into two sections Eumicrocos (African species) and section Podogynae (Asian species). The section Eumicrocos is distinguished from the simple androgynophore, short petal claws, small flowers, and presence of 4 - 6 ovules in the ovary [6]. Many species of the genus are still being treated as Grewia Linn. in Nigeria and West Africa. Previously, phylogenetic relationships of the Malvaceae s.l had been addressed using morphological data, pollen analysis, molecular data and anatomical data by [3] [18]-[21]. Anatomical data have provided valuable taxonomic information on the subfamily, tribe, generic and species levels for different groups of plants [22] [23], including the delimitation of species in the Malvaceae s.l. In recent years, anatomical characters have been employed in taxonomic delimitation [24]. Reference [25] stated that the leaf provides variety of anatomical features that can be of taxonomic utility. References [13] and [26] highlighted the anatomical features of the leaves in the genus Microcos in terms of stomata types and distribution, the presence of large crystals and mucilage canal or cavities distributed in the midrib and leaf lamina and types of trichomes, the secretory ducts and the crystals in the mesophyll as informative anatomical characters.

Although the genus Microcos has received considerable attention in Asia [2], information is sparse on the genus in West Africa. Moreover, in Nigeria, species of Microcos are usually recognized as Grewia. This study therefore is probably the first attempt to use leaves anatomical characters in the delimitation of the species of Microcos section Eumicrocos in Nigeria. In this study, six species vis: M. africana, Microcos barombiensis, $M$. coriacea, $M$. iodocarpa, M. malacocarpa and M. oligoneura were investigated.

\section{Materials and Methods}

\subsection{Source of Materials}

Dried herbarium materials of the species of Microcos section Eumicrocos studied were obtained from Forest Herbarium Ibadan (FHI) and University of Ibadan Herbarium (UIH). A fresh specimen of $M$. coriacea collected and identified by Shokefun E. O and Odewo from Aberu, Area J4, Ogun State, Nigeria was also used. The identification followed [4]. Table 1 gives the list of specimens studied.

\subsection{Leaf Sections}

Transverse sections of dried leaves of field collections or herbarium specimens were used for the study. The leaves were first irrigated by boiling in water until all the leaves sank in to the water. These were then transferred to $50 \%$ ethanol ready for sectioning. A $3 \mathrm{~cm}$ by $3 \mathrm{~cm}$ portion of the leaves were cut at the median position for sectioning. Transverse sections of the leaf were cut at $20 \mu$ thickness using Reichert Sledge Microtome and best sections preserved in 50\% ethanol. The sections were stained in $1 \%$ aqueous solution of Safranin $\mathrm{O}$ for 5 min washed in 3 changes of water at intervals of 3 mins to remove excess stain and counter stained in $1 \%$ solution of Alcian blue for 5 min then washed in three changes of water and dehydrated by passing through series of ethyl alcohol: 50\%, 70\%, 80\%, 90\% and 100\% with two changes in 100\% alcohol (dehydration process) at intervals of 10 - 15 mins and excess stain (differentiation process). The dehydrated and differentiated sections were cleared in xylene to remove last trace of water, to clear the sections (making it more transparent) and to remove last traces of ethanol and since xylene is the solvent of the mountant (DPX) used, it prevent cloudiness 
Table 1. List of specimens of Microcos section Eumicrocos studied.

\begin{tabular}{|c|c|c|c|c|c|}
\hline $\mathbf{S} / \mathbf{n}$ & Taxa & Locality & Names of collector & Voucher numbers & Date \\
\hline 1. & M. barombiensis & $\begin{array}{l}\text { Cross river, Nigeria } \\
\text { Abeokuta, Ogun, Nigeria } \\
\text { Ilaro, Ogun, Nigeria } \\
\text { Ikom, Edo, Nigeria } \\
\text { Ondo, Nigeria }\end{array}$ & $\begin{array}{l}\text { Emwiogbon \& Osanyinlusi } \\
\text { P. Wit \& B .O Daramola } \\
\text { P. P. C Van Meer } \\
\text { J. C Okafor \& M. G Latilo } \\
\text { C.F.A Onochie }\end{array}$ & $\begin{array}{c}\text { FHI } 86982 \\
64882 \\
22220 \\
57257 \\
33418\end{array}$ & $\begin{array}{c}4-10-77 \\
28-12-71 \\
14-8-68 \\
21-9-65 \\
29-7-73\end{array}$ \\
\hline 2. & M. iodocarpa & $\begin{array}{l}\text { Ondo, Nigeria } \\
\text { Oyo, Nigeria } \\
\text { Lagos, Nigeria } \\
\text { Ondo, Nigeria }\end{array}$ & $\begin{array}{c}\text { A.P.D Jones } \\
\text { R. W. J Keay \& A.P.D Jones } \\
\text { A. H Batten Poole } \\
\text { Oyeachusim, Onijamowo \& Ibhanesebhor }\end{array}$ & $\begin{array}{c}\text { FHI } 3591 \\
42020 \\
13296\end{array}$ & $\begin{array}{c}9-5-43 \\
4-11-45 \\
1946\end{array}$ \\
\hline 3. & M. coriacea & $\begin{array}{l}\text { Portharcort, Nigeria } \\
\text { Delta, Nigeria } \\
\text { Ondo, Nigeria } \\
\text { Benin, Nigeria } \\
\text { Ogun, Nigeria } \\
\text { J4, Ogun, Nigeria }\end{array}$ & $\begin{array}{l}\text { J. AEmwiogbon } \\
\text { Emwiogbon J. A } \\
\text { J. AEmwiogbon } \\
\text { J. Lowe } \\
\text { J. Lowe } \\
\text { Shokefun \& Odewo }\end{array}$ & $\begin{array}{c}\text { FHI } 60333 \\
89348 \\
56805 \\
\text { UIH } 21623 \\
20583 \\
\text { SEO } 012\end{array}$ & $\begin{array}{c}12-8-66 \\
8-11-76 \\
26-7-65 \\
8-3-91 \\
17-12-84 \\
10-06-09\end{array}$ \\
\hline 4. & M. africana & Ijebu, Ogun, Nigeria & C.Onochie \& Others & FHI 20675 & $26-1-47$ \\
\hline 5. & M. malacocarpa & $\begin{array}{c}\text { Owo, Ondo, Nigeria } \\
\text { Abeokuta, Ogun, Nigeria } \\
\text { Iwo, Osun, Nigeria } \\
\text { Ishan, Edo, Nigeria } \\
\text { Calabar, Nigeria } \\
\text { Ibadan, Oyo, Nigeria } \\
\text { Enugu, Nigeria } \\
\text { Delta, Nigeria }\end{array}$ & $\begin{array}{c}\text { J. P. D Jones } \\
\text { Wit. P \& Geerling C } \\
\text { J. K Adebusuyi } \\
\text { Ibhanesebhor, Odewo \& Oguntayo } \\
\text { Edwin Ujor } \\
\text { ILae Elderry } \\
\text { Emwiogbon J. A } \\
\text { Emwiogbon J. A }\end{array}$ & $\begin{array}{c}\text { FHI } 3465 \\
64989 \\
18239 \\
91141 \\
31643 \\
8202 \\
60363 \\
61108\end{array}$ & $\begin{array}{c}17-4-43 \\
11-3-72 \\
15-4-59 \\
19-5-79 \\
18-7-52 \\
4-1-45 \\
4-8-66 \\
20-3-68\end{array}$ \\
\hline 6. & M. oligoneura & Ikom, Edo, Nigeria & A.P.D Jones \& C.F Onochie & FHI 5806 & $14-5-46$ \\
\hline
\end{tabular}

of the slide. The sections were mounted in DPX mountant according to [27]. Photomicrographs of the leaf sections were taken with Leica CM E with Digital Microscope Eyepiece attachment and Photo Explorer 8.0 SE Basic software. Tissues and cells identification e.g. type of mesophyll, type of crystals, shape of vascular bundles and epidermal cell shapes were done following the work of [28]-[30].

\section{Result}

General anatomical characters of the species in section Eumicrocos, genus Microcos in Nigeria.

\subsection{Cuticle}

The cuticle on the outer wall of the epidermal cells of the adaxial and abaxial surfaces is smooth in all the studied taxa (Table 2). The cuticle is equally thin on both adaxial and abaxial surface in most species, except $M$. coriacea in which the cuticle on the adaxial surface is thicker than that of the abaxial surface (Figure 1(h)). The epidermis is mostly single-layered and generally thicker at the adaxial side of the leaf. The adaxial epidermal cells are larger than the abaxial epidermal cells and are horizontally elongated but can also be square (M. oligoneura) or vertically elongated (Figure 2(f)).

\subsection{Mesophyll}

The mesophyll is bifacial with predominantly two layers of cylindrical palisade cells and a 3 - 4 layered polygonal shaped spongy cells (Table 2). In the palisade of $M$. coriacea and $M$. oligoneura, some long palisade cells are subdivided (Figure 1(h) \& Figure 2(f)). The bundle sheath is composed of both parenchyma and sclerenchyma cells. All the species studied were vertically translucent.

\subsection{Indumentums}

Glandular and non-glandular hairs can be found on both young and adult parts while in a few cases, non glandular hairs may be caducous in the adult leaves. In most of the species, the glandular hairs are elongated, obovoid 
Table 2. Anatomical characters of the lamina of some species of Microcos section Eumicrocos in Nigeria.

\begin{tabular}{|c|c|c|c|c|c|c|c|c|c|c|c|c|}
\hline \multirow{3}{*}{$\mathbf{S} / \mathbf{n}$} & \multirow{3}{*}{ Taxa } & \multicolumn{2}{|c|}{ Cuticle } & \multicolumn{4}{|c|}{ Epidermis } & \multicolumn{2}{|c|}{ Mesophyll } & \multicolumn{2}{|c|}{ Starch grain } & \multirow[t]{2}{*}{$\begin{array}{c}\text { Types of } \\
\text { crystal }\end{array}$} \\
\hline & & \multicolumn{2}{|c|}{ Ornamentation Thickness } & \multicolumn{2}{|c|}{ Cell } & \multicolumn{2}{|c|}{ Trichome } & \multirow{2}{*}{\multicolumn{2}{|c|}{ Palisade Spongy }} & \multicolumn{2}{|c|}{$\begin{array}{l}\text { Type of } \\
\text { leaves }\end{array}$} & \\
\hline & & & Adaxial & Adaxial & Abaxial & Adaxial & Abaxial & & & & & \\
\hline 1. & $\begin{array}{c}M . \\
\text { africana }\end{array}$ & Smooth & Thin & Polygonal & Polygonal & $\begin{array}{l}\text { S, Ss } 3 \text { - } 4 \\
\text { armed, } 3 \text { - } 4 \\
\text { celled ust } \\
\& \text { mct }\end{array}$ & $\begin{array}{c}3 \text { - } 4 \\
\text { armed, } \\
\text { S \& Ss }\end{array}$ & 2 & 3 & Bifacial & Mesophyll & $\begin{array}{c}\text { Prismatic, } \\
\text { Styloid, } \\
\text { druses }\end{array}$ \\
\hline 2. & $\begin{array}{c}M . \\
\text { barombiensis }\end{array}$ & Smooth & Thin & Polygonal & Polygonal & $\begin{array}{l}\text { S, 4-celled } \\
\text { mct }\end{array}$ & $\begin{array}{l}2 \text { - } 4 \text { armed, } \\
3 \text { celled ust }\end{array}$ & 2 & 3 & Bifacial & Absent & $\begin{array}{l}\text { Styloid, } \\
\text { druses }\end{array}$ \\
\hline 3. & $\begin{array}{c}M . \\
\text { coriacea }\end{array}$ & Smooth & Thick & Polygonal & Polygonal & $\begin{array}{l}\text { 3-4 celled } \\
\text { mct }\end{array}$ & $\begin{array}{l}\text { Ss, } 3 \text { - } 4 \\
\text { armed, } 4 \text { - } 5 \\
\text { celled ust } \\
\quad \& \text { mct }\end{array}$ & 2 & $3-4$ & Bifacial & Mesophyll & $\begin{array}{c}\text { Prismatic, } \\
\text { Styloid, } \\
\text { druses }\end{array}$ \\
\hline 4. & $\begin{array}{c}M . \\
\text { iodocarpa }\end{array}$ & Smooth & Thin & Polygonal & Polygonal & $\begin{array}{c}\text { S, Ss, } 3 \text { - } 4 \\
\text { armed } 3 \text { - } 4 \\
\text { celled ust } \\
\text { \& mct }\end{array}$ & $\begin{array}{c}2 \text { - } 4 \text { armed, } \\
\text { Ss, S \& } \\
3 \text { - } 4 \text { celled } \\
\text { ust }\end{array}$ & 2 & 3 & Bifacial & Absent & Druses \\
\hline 5. & $\begin{array}{c}M . \\
\text { malacocarpa }\end{array}$ & Smooth & Thin & $\begin{array}{l}\text { Rectangular/ } \\
\text { polygonal }\end{array}$ & Polygonal & $\begin{array}{l}\text { Ss, S, } 3 \text { - } 4 \\
\text { celled ust } \\
\text { \& mct }\end{array}$ & $\begin{array}{c}\text { Ss, } 3 \\
\text { celled ust }\end{array}$ & 2 & 3 & Bifacial & $\begin{array}{l}\text { Epidermal } \\
\text { cells }\end{array}$ & $\begin{array}{c}\text { Prismatic, } \\
\text { Styloid, } \\
\text { druses }\end{array}$ \\
\hline 6. & $\begin{array}{c}M . \\
\text { oligoneura }\end{array}$ & Smooth & Thin & Rectangular & Rectangular & $\begin{array}{c}\text { S, } 3 \\
\text { celled ust }\end{array}$ & $\begin{array}{c}3 \\
\text { celled ust }\end{array}$ & 2 & $4-5$ & Bifacial & Absent & Druses \\
\hline
\end{tabular}

Key Stau = staurocytic stomata, Ani = anisocytic stomata, Para = paracytic stomata, $\mathrm{S}=$ simple trichome, Ss $=$ stellate trichome, Mct $=$ multicellular glandular trichome, ust = uniseriate glandular trichome, 2 - 4 armed $=2$ - 4 branched non glandular trichomes.

with 2 to 5 celled heads (Table 2). Simple hairs are mostly single-celled with pointed tips and common on the lamina of most species but absent on the abaxial surfaces in M. barombiensis, M. malacocarpa, M. oligoneura and on both surfaces in M. coriacea (Table 2). In some species, such as M. africana and M. iodocarpa 3 - 4 armed branched hairs are found on both surfaces while it was only observed on the abaxial surfaces in $M$. barombiensis and M. coriacea but absent in other species (Table 2). However, 2-armed Y-shaped or V-shaped branched trichomes was recorded only in $M$. barombiensis and $M$. iodocarpa respectively.

\subsection{Crystals}

Three types of crystals are common to the leaf of the section Eumicrocos. Prismatic and styloid crystals are recorded in the cortex, xylem and medullary cells in the midrib of most species but absent in M. iodocarpa and $M$. oligoneura (Table 3). It is also present in the palisade tissue region and bundle sheaths above and below the veins in is section but absent in M. iodocarpa and M. oligoneura (Table 2). Druse is commonly present in the cortex parenchyma cells, vascular bundles, bundle sheaths, palisade and spongy mesophyll in all the species studied.

\subsection{Midrib}

The outline of the midrib in transverse sections at the adaxial surface is convex but almost flat in M. oligoneura (Figure 2(g)). The abaxial surface is protruded with round bases of all the species. The species possesses a u-shaped amphicribral vascular bundle surrounded by sclereid cells (Table 3; Figure 1(c), Figure 1(e), Figure 1(i) \& Figure 2(c), Figure 2(e), Figure 2(g)). One to two small accessories bundles and one large u-shaped incurved vascular bundle were recorded in M. oligoneura while a central medullary plate was recorded in $\mathrm{M}$. coriacea (Figure 1(i) \& Figure 2(h)). One to five layers of sclerenchyma cells are associated with the phloem or xylem in most species (Table 3). Surrounding the vascular structure of most species is a thin-walled parenchyma cell. 

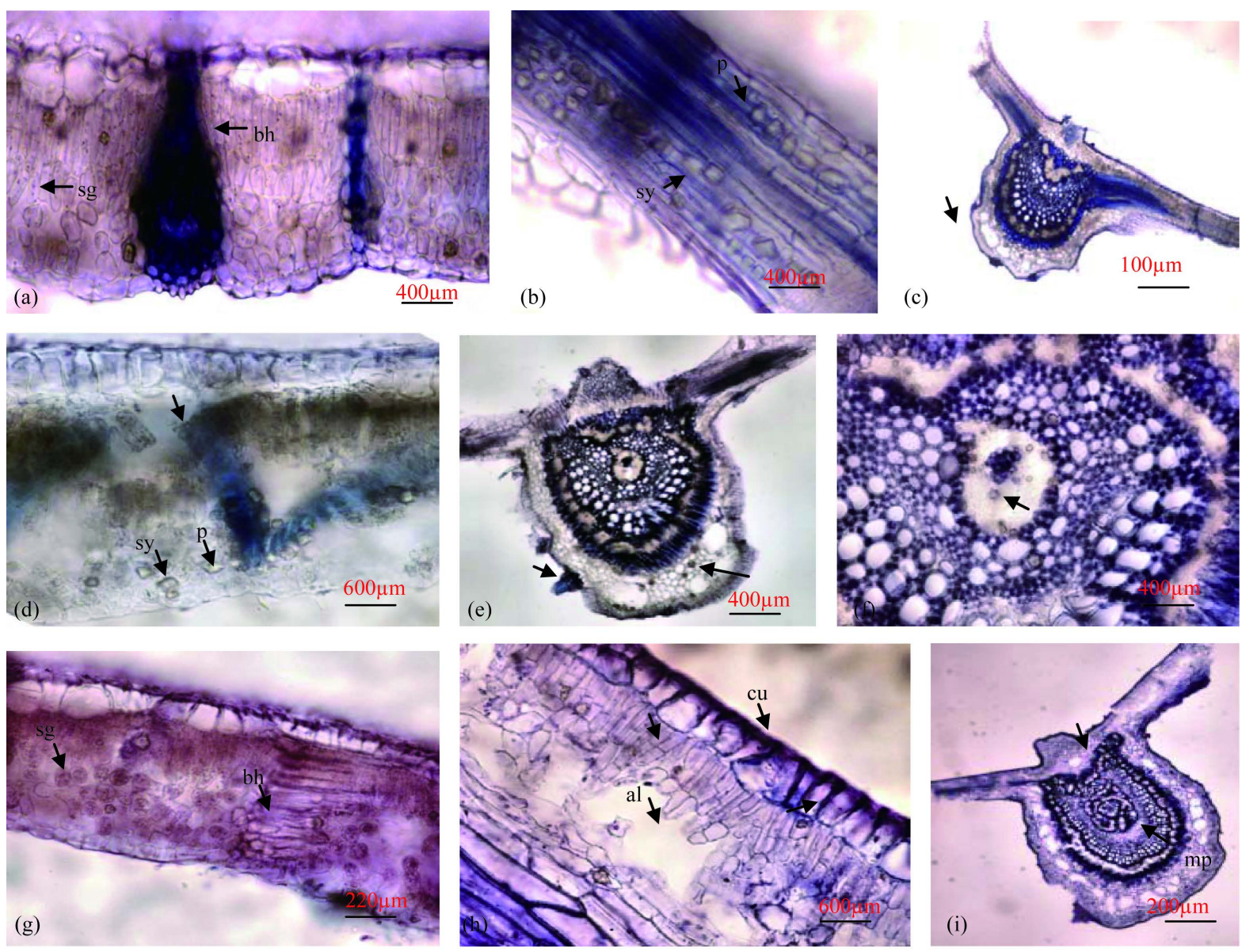

Figure 1. Photomicrogrphs of transverse leaf section features of Microcos species. (a)-(c) M. africana lamina showing, starch grains in the mesophyll and bundle sheath extending to both epidermises, (b) lamina showing prismatic, styloid and druse crystals arranged in chain in the fibre, (c) midrib showing the secretory duct on the abaxial side and the u-shape vascular bundle; (d)-(f) M. barombiensis lamina showing styloid and prismatic crystal in the spongy cells and palisade cells with starch grains, (e) midrib showing remnant of simple trichomes and druses in the cortex region, (f) midrib showing druses in the medullary region; (g)-(i) M. coriacea, lamina showing starch grains in the mesophyll and bundle sheath, (h) lamina showing palisade cell subdivided, large air lacunar and a vertically arranged epidermal cells, (i) midrib showing medullary plate, a secretory duct on the adaxial side and many secretory ducts on the abaxial side. $d=$ druses, $p=$ prismatic crystal, $\mathrm{mp}$ = medullary plate, $\mathrm{cu}$ = cuticle, al = air lacunar, $\mathrm{bh}$ = bundle sheath, sy = styloid crystal. Stain: Safranin and Alcian blue.

\subsection{Secretory Ducts and Starch Grains}

Secretory ducts are usually associated with the cortex region of the abaxial surface and variable in numbers from 2 - 20 in the midrib of species in the section. On the adaxial surface of the cortex, 1 - 2 secretory ducts were recorded in M. coriacea and M. iodocarpa (Figure 1(i) \& Figure 2(c)). Starch grains were present in the mesophyll of M. africana and M. coriacea and the epidermal cells in M. malacocarpa (Table 2; Figure 1(a), Figure 1(g) \& Figure 2(i)).

\section{Discussion}

The present study shows that leaves anatomical characters of the genus is typical of the Tiliaceae that has been reported on previous studies [13] [31] [32]. The anatomical characters of the genus Microcos are constant for the genus whereas some characters are different and useful for distinguishing between species. The generalized anatomical characteristics of all species of Microcos section Eumicrocos are as follows: (1) the one-layered epidermal cells. (2) the hypostomatic and bifacial leaves; (3) Presence of 2 layers of palisade tissues; (4) The presence of bundle sheaths which extends to both epidermises; (5) presence of glandular and non glandular trichomes 

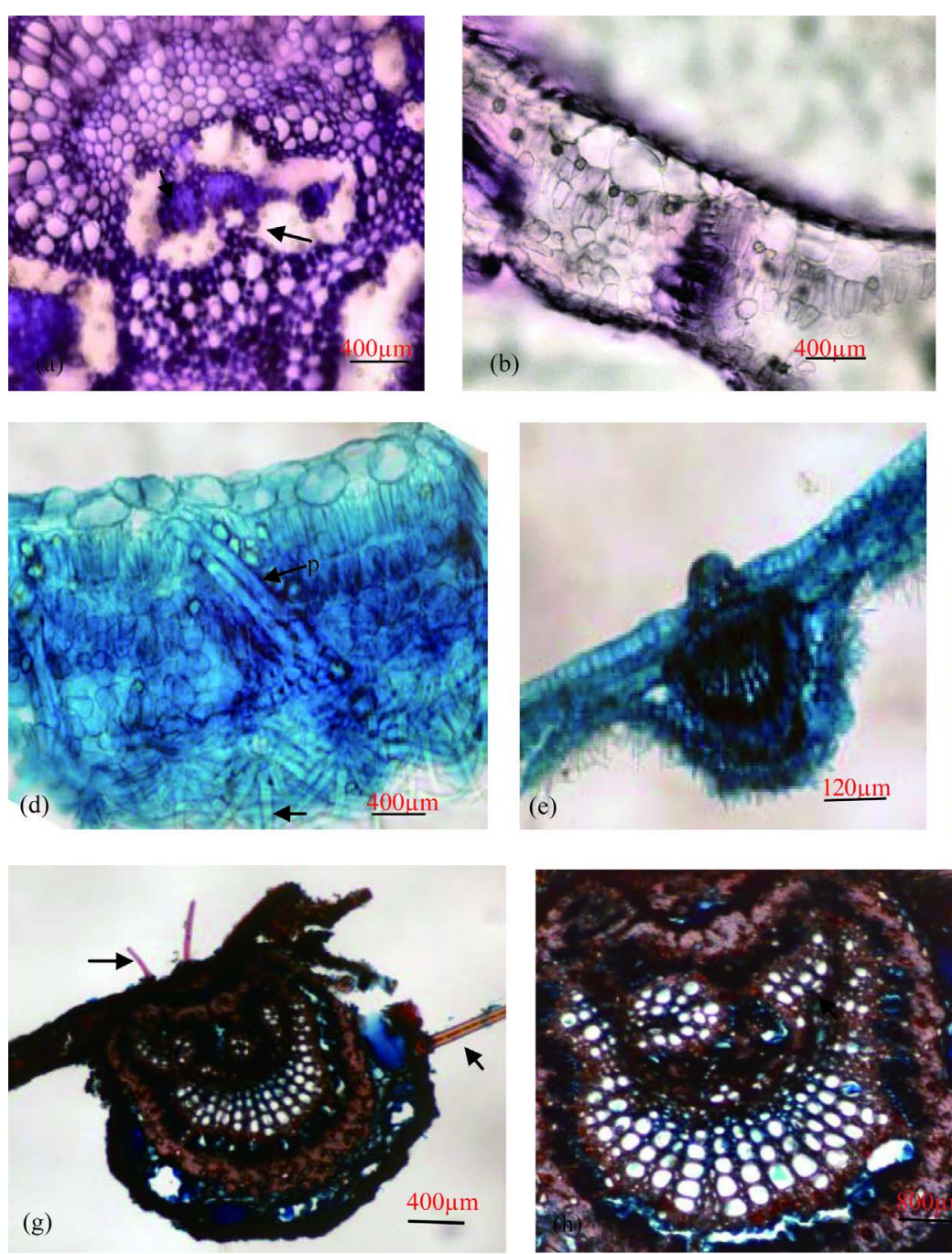
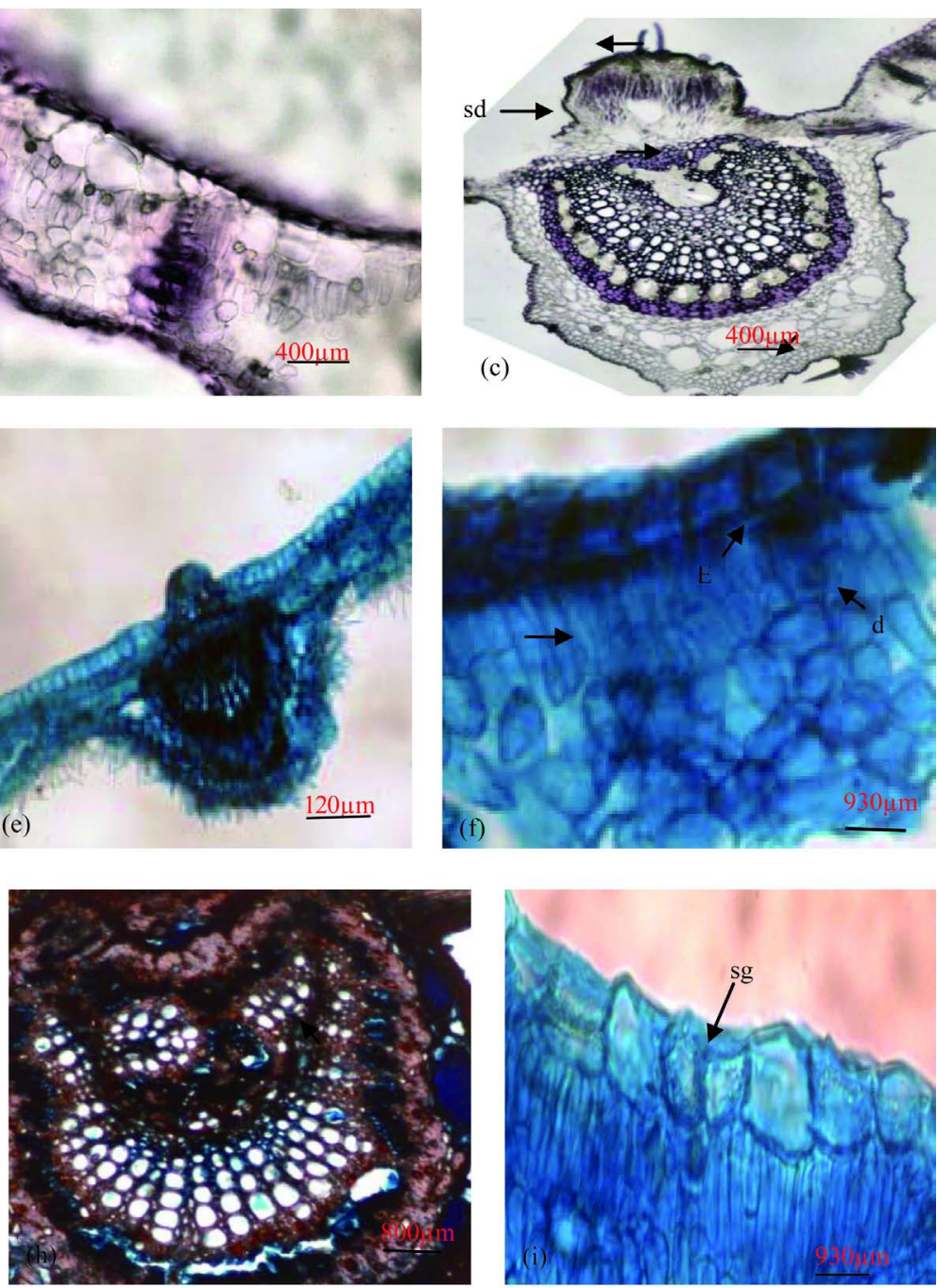

Figure 2. Photomicrographs of transverse leaf section features of Microcos species. (a) M. coriacea midrib showing sclereid cells and druses in the medullary region, (b), (c) M. iodocarpa lamina showing prismatic, styloid and druse crystals arranged in chain in the fibre, (c) midrib showing the secretory duct on the abaxial side and the u-shape vascular bundle; (d), (e) $M$. malacocarpa lamina showing prismatic crystal in the mesophyll and dense distribution of stellate hairs on the abaxial surface, (e) midrib showing u-shaped vascular structure with knot-shaped adaxial outline; (f)-(h) M. oligoneura lamina showing subdivided palisade cells and druses in the palisade cells, (g) midrib showing an almost flat adaxial surface, simple hairs on both surfaces, (h) showing two accessory vascular bundles; (i) M. malacocarpa lamina showing starch grains in the adaxial epidermal cells. sg = starch grain, sd = secretory duct, $\mathrm{E}=$ epidermal cell. Stain: Safranin and Alcian blue.

on the leaves; (6) the presence of secretory ducts on the abaxial surfaces in the midrib; and (7) the presence of druses in the mesophyll and midribs. The number of spongy cells layers in the lamina, number of sclerenchyma cells associated with the phloem and number of secretory ducts on the abaxial region of the midrib and the number of glandular trichomes cell head are helpful in dividing the genus into two groups. According to [4], six species in Microcos, section Eumicrocos have been recorded in Nigeria; two species in subsection Integristipulae Burret (M. coriacea, M. malacocarpa), three species in subsection Digitatae Burret (M. barombiensis, M. africana and M. iodocarpa) and one in subsection Pinnatifidae Burret (M. oligoneura). The first group consists of M. barombiensis, M. africana and M. iodocarpa which has three layer of spongy cells, 2 - 3 layers of sclereid cells associated with the phloem, absence of sclereid cells and medullary plate in the medullary region of the midrib. In contrast to the first group, the second but diverse group consisting of $M$. coriacea, M. malacocarpa and M. oligoneura has variable spongy cell layers, and sclereid cells associated with the phloem in the midrib. The groups obtained in this study based on the anatomical characters supported the sub sectional delimitation of 
Table 3. Anatomical characters of the midrib of some species of Microcos section Eumicrocos in Nigeria.

\begin{tabular}{|c|c|c|c|c|c|c|c|c|c|c|c|c|c|}
\hline \multirow{2}{*}{$\mathrm{S} / \mathbf{n}$} & \multirow{2}{*}{ Taxa } & \multicolumn{2}{|c|}{ Outline } & \multicolumn{2}{|c|}{$\begin{array}{c}\text { Number of } \\
\text { Secretory ducts }\end{array}$} & \multicolumn{2}{|c|}{ Vascular bundle } & \multirow[t]{2}{*}{$\begin{array}{l}\text { Type of } \\
\text { crystal }\end{array}$} & \multirow[t]{2}{*}{$\begin{array}{c}\text { Cell } \\
\text { inclusions }\end{array}$} & \multicolumn{3}{|c|}{ Sclerenchyma cells in } & \multirow{2}{*}{$\begin{array}{c}\text { Medullary } \\
\text { plate }\end{array}$} \\
\hline & & Adaxial & Abaxial & Adaxial & Abaxial & shape & $\begin{array}{l}\text { Number } \\
\text { of stands }\end{array}$ & & & Phloem & Xylem & $\begin{array}{l}\text { Number } \\
\text { of layers }\end{array}$ & \\
\hline 1. & M. africana & Convex & $\begin{array}{l}\text { Protruded } \\
\text { round } \\
\text { base }\end{array}$ & Absent & $4-6$ & u-shaped & 1 & $\begin{array}{c}\text { Prismatic, } \\
\text { styloid, } \\
\text { druses }\end{array}$ & Absent & Present & Absent & $2-3$ & Absent \\
\hline 2 & $\begin{array}{c}M . \\
\text { barombiensis }\end{array}$ & Convex & $\begin{array}{l}\text { Protruded } \\
\text { round } \\
\text { base }\end{array}$ & Absent & 4 & u-shaped & 1 & $\begin{array}{c}\text { Prismatic, } \\
\text { styloid, } \\
\text { druses }\end{array}$ & Absent & Present & Absent & $2-3$ & Absent \\
\hline 3. & M. coriacea & Convex & $\begin{array}{l}\text { Protruded } \\
\text { round } \\
\text { base }\end{array}$ & 2 & $8-20$ & $\begin{array}{c}\text { Closed } \\
\text { u-shaped }\end{array}$ & 1 & $\begin{array}{c}\text { Prismatic, } \\
\text { styloid, } \\
\text { druses }\end{array}$ & $\begin{array}{l}\text { Starch } \\
\text { grains }\end{array}$ & Present & Present & $1-5$ & Present \\
\hline 4. & $\begin{array}{c}M . \\
\text { iodocarpa }\end{array}$ & Convex & $\begin{array}{l}\text { Protruded } \\
\text { round } \\
\text { base }\end{array}$ & 2 & $4-8$ & u-shaped & 1 & Druses & Absent & Present & Absent & $2-3$ & Absent \\
\hline 5. & $\begin{array}{c}M . \\
\text { malacocarpa }\end{array}$ & Convex & $\begin{array}{l}\text { Protruded } \\
\text { round } \\
\text { base }\end{array}$ & Absent & 2 & u-shaped & 1 & $\begin{array}{c}\text { Prismatic } \\
\text { styloid, } \\
\text { druses }\end{array}$ & Absent & Present & Absent & $1-4$ & Absent \\
\hline 6. & $\begin{array}{c}M . \\
\text { oligoneura }\end{array}$ & Flat & $\begin{array}{l}\text { Protruded } \\
\text { round } \\
\text { base }\end{array}$ & Absent & $8-10$ & u-shaped & 3 & Druses & Absent & Present & Present & $1-5$ & Present \\
\hline
\end{tabular}

the genus by [33]. In the Nigerian Microcos, the cuticle ornamentation on both the adaxial and abaxial surfaces is smooth, equally thickened on both surfaces, or thicker on the adaxial surface than that of the abaxial surface as recorded in $M$. coriacea (Table 1). The adaxial epidermal cells are larger than the abaxial epidermal cells and are horizontally elongated but can also be square or vertically elongated. Reference [30] reported straight to curve or wavy anticlinal cell wall for the genus. The stomata is raised and restricted to the abaxial surface only. Reference [30], had earlier reported anisocytic, paracytic and staurocytic stomata types for the Nigerian species of Microcos in contrast to [13] [31] [34], who only recognized tetracytic and anomocytic stomata in the genus. The trichomes are usually present at both surfaces, even in species that are glabrous. Three trichome types are observed in this study: 1) Simple unbranched and 2 - 4 armed branched trichomes; 2 ) 3 - 5 celled head elongated uniseriate and multicellular glandular trichomes with single celled stalk; and 3) sessile and stalked stellate trichomes. Reference [35] pointed out the diagnostic value of the number of cells in the capitate glandular trichome heads. The leaf is bifacial with well differentiated palisade and spongy tissue regions. The number of spongy tissue layers is of taxonomic value of separating the species in the section. In all the species, sclereid cells are found in the mesophyll and midrib associated with the xylem or the phloem. Reference [36] noted that this character is diagnostic for a specific level. The vascular bundles in the midrib are usually u-shaped incurved or a closed ring vascular structure surrounding a central medullary region. The presence of 1 to 2 accessories bundles in $M$. oligoneura and a medullary plate in a closed ring in $M$. coriacea is diagnostic in for both species. The bundle sheath extensions of both epidermises were present in all species studied. Secretory structures are of great taxonomic interest and their restricted distribution is of taxonomic value. The secretory ducts in this study are distributed in the medullary or cortex region and at times in both regions around the vascular bundles in the midrib in most species. However, the presence of secretory ducts in the adaxial region in the midrib of $M$. coriacea and $M$. iodocarpa is diagnostic for the two species. The numbers of secretory ducts in the midrib vary from the different species and are of taxonomic value in this study. Reference [26] [36] [37], reported that the variation in vascular structure and the number and distribution of secretory canals or cavity are apparently highly distinctive in different genera and species. In addition, druses were commonly found in all species, while prismatic and styloid crystals were present only in some species. Reference [38], highlighted the taxonomic importance of crystal and further emphasizes the mode of distribution of equally important taxonomic tools. Reference [30], reported both druses, prismatic and styloid crystals in a few species in the section Eumicrocos. However, the absence of styloid and prismatic crystals in the leaf of $M$. iodocarpa and M. oligoneura is diagnostic for the species. Starch grains were present in the mesophyll of $M$. coriacea and M. iodocarpa and in the 
epidermal cells in M. malacocarpa. This character is diagnostic for the three species.

The results revealed a number of interesting features that may be useful for identification of some closely related species which are as follows: M. africana and M. iodocarpa: these two species have very similar morphological characters and current identification between them is based upon the leaf base and hair on the leaf abaxial surface. Here based on the leaf anatomical characters, $M$. iodocarpa can be distinguished from $M$. africana by the presence of secretory ducts at the adaxial region of the midrib, presence of starch grains in the mesophyll, presence of only druses in the mesophyll and presence of V-shaped 2-armed branched trichomes on the abaxial surface of the lamina.

\section{Key to the Species of Microcos in the Section Eumicrocos}

1. Spongy tissue layers not more than 3; sclereid associated with phloem 2 - 3 layers; sclereid absent in xy-

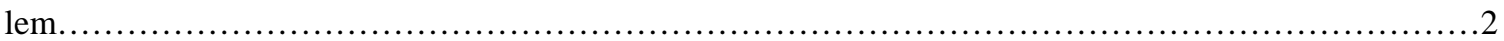

1. Spongy tissue layers up to 5; sclereid associated with phloem1-5 layers; sclereid present or absent in xylem. . .4

2. Y to V-shaped branched trichomes present in lamina, 3 - 4 celled head capitate glandular hairs present on the abaxial surface; stellate and simple hairs absent or present; midrib abaxial secretory duct $4-8 \ldots \ldots . .3$

2. Y to V-shaped branched trichome absent in lamina glandular trichome absent on the abaxial surface, stellate and simple hairs present; midrib abaxial secretory duct not more than 6.........Microcos africana

3. Midrib adaxial secretory duct absent; abaxial secretory ducts not more than 4; prismatic, styloid and druses crystals present in midrib. Microcos barombiensis

3. Midrib adaxial secretory duct present; abaxial secretory ducts up to 8; prismatic and styloid crystals absent. Microcos iodocarpa

4. Midrib abaxial secretory ducts not more than 2; spongy tissue 3 layers; medullary plate absent; starch grains present in epidermal cells........................................crocos malacocarpa

4. Midrib abaxial secretory ducts 8 - 20; spongy tissue 3 - 5 layers; medullary plate present; starch grains absent or present.

5. Midrib adaxial outline convex; epidermal cells polygonal; starch grains present in mesophyll; midrib adaxial secretory ducts present; prismatic, styloid crystal present; glandular trichomes 2 5 celled head.

Microcos coriacea

5. Midrib adaxial outline flat; epidermal cell rectangular; starch grain absent in mesophyll; midrib adaxial secretory ducts absent; prismatic and styloid crystals absent; glandular trichomes 3 celled head. ..... ..Microcos oligoneura

\section{Conclusion}

In conclusion, the leaf anatomical data of Nigeria Microcos section Eumicrocos have apparently informative characters for solving species delimitation problem and are useful for identification of morphologically closely related species because these characters appear to be consistent and distinguishable between species. The anatomical characters of taxonomic significance for the delimitation of the species in the present investigation are the number of spongy cell layers in the lamina, number of sclerenchyma cells associated with the phloem, number of secretory ducts on the abaxial region of the midrib and the number of cells in the glandular trichomes. The results obtained in the present study corroborate the delimitation of the species based on morphological data [33] and foliar epidermal and pollen character earlier reported by [30].

\section{References}

[1] Bayer, C. and Kubitzki, K. (2003) Malvaceae. In: Kubitzki, K., Ed., The Families and Genera of Vascular/Plants, Vol. 5, Malvales, Capparales and Non-Betalain Caryophyllales, 225-311.

[2] Chung, R.C.K., Soepadmo, E. and Lim, A.L. (2003) The Significance of Pollen Morphology in the Taxonomy of Grewia and Microcos (Tiliaceae) in Peninsular Malaysia and Borneo. The Gardens Bulletin Singapore, 55, 239-256.

[3] Brunken, U. and Muellner, A.N. (2012) A New Tribal Classification of Grewioideae (Malvaceae) Based on Morphological and Molecular Phylogenetic Evidence. Systematic Botany, 37, 699-711.

http://dx.doi.org/10.1600/036364412X648670 
[4] Hutchinson, J. and Dalziel, J.M. (1954) Flora of West Tropical Africa. 2nd Edition, Crown Agents for overseas Governments Administrations, London, Vol. I, Part 1.

[5] Chung, R.C.K., Soepadmo, E. and Lim, A.L. (2011) Taxonomic Revision of the Genus Microcos L. (MalvaceaeGrewioideae) in Peninsular Malaysia and Borneo. Blumea, 56, 273-299. http://dx.doi.org/10.3767/000651911X619704

[6] Burret, M. (1926) Beiträge zur Kenntnis der Tiliaceen. Notizblatt des Botanischen Gartens und Museum zu BerlinDahlem, 9, 592-880. http://dx.doi.org/10.2307/3994327

[7] Burkill, H.M. (1985) The Useful Plants of West Tropical. Vol. 5. Family S-Z. 2nd Edition, Royal Botanical Gardens. Kew.

[8] Czarnecka, E., Wiland-Szymanska, J. and Gawronska, K. (2006) Phytogeography of the Genus Microcos L. (Malvaceae, Grewioidae) in Africa. Biodiversity: Research and Conservation, 34, 269-271.

[9] Chung, R.C.K. (2003) New Taxa and New Combinations of Microcos (Tiliaceae) from Peninsular Malaysia and Borneo. Kew Bulletin, 58, 329-349. http://dx.doi.org/10.2307/4120619

[10] Chung, R.C.K., Seopadmo, E. and Lim, A.L. (2005) A Synopsis of the Bornean Species of Microcos L. (Tiliaceae). Gardens' Bulletin of Singapore, 57, 101-130.

[11] Cheek, M.R. (2007) Sparrmanniaceae. In: Heywood, V.H., Brummitt, R.K. and Culham, A., Eds., Flowering Plant Families of the World, Royal Botanic Gardens, Kew, 307-308.

[12] Chattaway, M.M. (1934) Anatomical Evidence that Grewia and Microcos Are Distinct Genera. Tropical Woods, 38, 9-11.

[13] Metcalfe, C.R. and Chalk, L. (1979) Anatomy of Dicotyledons. Vol. 1. Systematic Anatomy of Leaf and Stem, with a Brief History of the Subject. 2nd Edition, Clarendon Press, Oxford, 40-41.

[14] Chung, R.C.K., Lim, S.C., Lim, A.L. and Soepadmo, E. (2005) Wood Anatomy of Grewia and Microcos from Peninsular Malaysia and Borneo. Journal of Tropical Forest Science, 17, 175-196.

[15] Mabberley, D.J. (2008) A Portable Dictionary of Plants, Their Classifications and Uses. 3rd Edition, Cambridge University Press, Cambridge.

[16] Sowunmi, M.A. (1973) Pollen Grains of Nigerian Plants. Grana, 13, 145-186. http://dx.doi.org/10.1080/00173137309429891

[17] Perveen, A., Grafstrom, E. and El-Ghazaly, G. (2004) World Pollen and Spore Flora 23. Malvaceae Adams. P.p. Subfamilies: Grewioideae, Tilioideae, Brownlowioideae. Grana, 43, 129-155. http://dx.doi.org/10.1080/00173130410000730

[18] Bayer, C., Fay, M.F., De Bruijn, A.Y., Salvolainen, V., Morton, C.M., Kubitzki, K., Alverson, W.S. and Chase, M.W. (1999) Support for an Expanded Family Concept of Malvaceae within a Recircumscribed Order Malvales: A Combined Analysis of Plastid atpB and $r b c$ L DNA Sequences. Botanical Journal of Linnaeus Society, 129, 267-303. http://dx.doi.org/10.1111/j.1095-8339.1999.tb00505.x

[19] Judd, W.S., Campbell, C.S., Kellog, E.A. and Stevens, P.F. (1999) Plant Systematics-A Phylogenetic Approach. Sinauer Associates, Sunderland.

[20] Alverson, W.S., Karol, K.G., Baum, D.A., Chase, M.W., Swensen, S.M., McCourt, R. and Sytsma, K.J. (1999) Circumscription of the Malvales and Relationship to Other Rosidae: Evidence from $r b c L$ Sequence Data. American Journal of Botany, 85, 876-887. http://dx.doi.org/10.2307/2446423

[21] The Angiosperm Phylogeny Group (2003) An Update of the Angiosperm Phylogeny Group Classification for the Orders and Families of Flowering Plants: APG II. Botanical Journal of the Linnaean Society, 141, 399-436. http://dx.doi.org/10.1046/j.1095-8339.2003.t01-1-00158.x

[22] Stuessy, T.F. (1990) Plant Taxonomy. The Systematic Evolution of Comparative Data. Columbia University Press, New York, 514 p.

[23] Stuessy, T.F. (2009) Plant Taxonomy. The Systematic Evolution of Comparative Data. 2nd Edition, Columbia University Press, New York.

[24] Kharazian, N. (2007) The Taxonomy and Variation of Leaf Anatomical Characters in the Genus Aegilops L. (Poaceae) in Iran. Turkish Journal of Botany, 31, 1-9.

[25] Carlquist, S. (1961) Comparative Plant Anatomy. Holt, Rinchart and Winston, New York, 29-36.

[26] Fahn, A. (1982) Plant Anatomy. Pergamon Press, Oxford, 545 p.

[27] Akinloye, A.J., Illoh, H.C. and Olagoke, O.A. (2012) Significance of Wood Anatomical Features to the Taxonomy of Five Cola Species. Sustainable Agriculture Research, 1, 21-26.

[28] Metcalfe, C.R. and Chalk, L. (1989) Anatomy of the Dicotyledons. Vol. II, 2nd Edition, Clarendon Press, Oxford, 98-116. 
[29] Ayodele, A.E. and Olowokudejo, J.D. (1997) Systematic Importance of Leaf and Epidermal Characters in West African Species of Family Myrtaceae. Boletim da Sociedade Broteriana, 68, 35-72.

[30] Shokefun, E.O., Orijemie, E.A. and Ayodele, A.E. (2014) Foliar Epidermal and Pollen Characters of Some Species in the Genus Microcos Linn. in Nigeria. American Journal of Plant Sciences, 5, 3904-3913. http://dx.doi.org/10.4236/ajps.2014.526409

[31] Solereder, H. (1908) Systematic Anatomy of the Dicotyledons: A Handbook for Laboratories of Pure and Applied Botany. Vol. 2, Clarendon Press, Oxford.

[32] Nurul-aini, C.A.C., Noraini, T., Latiff, A., Chung, R.C.K., Nurhanim, M.N. and Ruzi, M. (2013) Systematic Significance of Petiole Anatomical Characteristics in Microcos L. (Malvaceae: Grewioideae). Malayan Nature Journal, 65, 145-170.

[33] Burret, M. (1910) Die afrikanischen Arten der Gattung Grewia L. Botanische Jahrbücher für Systematik, 45, $156-203$.

[34] Metcalfe, C.R. and Chalk, L. (1985) Anatomy of the Dicotyledons. Vol. 2, Clarendon Press, Oxford.

[35] Serrato-Valenti, G., Bisio, A., Cornara, L. and Cirallo, G. (1997) Structural and Histochemical Investigation of the Glandular Trichomes of Salvia aurea L. Leaves, and Chemical Analysis of the Essential Oil. Annals of Botany, 79, 329-336. http://dx.doi.org/10.1006/anbo.1996.0348

[36] Metcalfe, C.R. and Chalk, L. (1957) Anatomy of the Dicotyledons. Vol. 2, Clarendon Press, Oxford, 557.

[37] Metcalfe, C.R. and Chalk, L. (1950) Anatomy of the Dicotyledons. Vol. 1, Clarendon Press, Oxford, 243-245.

[38] Ter Welle, B.J.H. (1979) Silica Grains in Woody Plants in Neotropics, Especially Surinam. Mededelingen van het Botanisch Museum en Herbarium van de Rijksuniversiteit te Utrecht, 439, 107-142. 